\title{
Antisense Oligodeoxynucleotide to the Cystic Fibrosis Transmembrane Conductance Regulator Inhibits Cyclic AMP-activated but not Calcium-activated Cell Volume Reduction in a Human Pancreatic Duct Cell Line
}

\author{
H. Kopelman, C. Gauthier, and M. Bornstein \\ Division of Gastroenterology, Montreal Children's Hospital-McGill University Research Institute, Montreal, H3H IP3 Quebec, Canada
}

\begin{abstract}
Cystic fibrosis (CF) is characterized by a defect in cAMP-regulated chloride channels in epithelial cells. The CF gene product CF transmembrane conductance regulator (CFTR) is expressed in the apical membrane of pancreatic duct cells, and mutant CFTR accounts for the pathology in the CF pancreas. PANC 1, a pancreatic duct cell line, has not been considered a good model for studying CFTR and pancreatic chloride transport because CFTR mRNA and protein are undetectable using standard methods. Using electronic cell sizing and cell volume reduction under isotonic conditions, PANC 1 cells were found to possess both CAMP and calcium-activated chloride conductances. Using CFTR antisense oligodeoxynucleotides, the cAMP-activated conductance could be specifically inhibited in a concentration- and time-dependent manner. These findings demonstrate that PANC 1 cells express CFTR and a CFTR-independent calcium-activated chloride channel. With electronic cell sizing and CFTR antisense oligodeoxynucleotides, PANC 1 cells can provide an ideal system for the study of pancreatic duct cell physiology and pathophysiology with respect to the role of CFTR in the pancreas. These findings also suggest that antisense oligodeoxynucleotides may provide a more sensitive yet highly specific means of detecting low levels of expression of CFTR than currently available. (J. Clin Invest. 1993. 91:1253-1257.) Key words: cystic fibrosis • PANC $1 \cdot$ chloride transport $\bullet$ cell volume studies $\bullet$ antisense oligodeoxynucleotides • cystic fibrosis transmembrane conductor
\end{abstract}

\section{Introduction}

Cystic fibrosis (CF), ${ }^{1}$ the most common lethal genetic disorder in Caucasians, is characterized by the clinical triad of chronic lung disease, pancreatic insufficiency, and elevated sweat electrolyte concentrations. Over the past decade, two important findings have changed our understanding of this disease: the recognition that apical chloride channel activation by cAMP is

Address correspondence to H. Kopelman, 2300 Tupper D596, Montreal, H3H 1P3 Quebec, Canada.

Received for publication 15 July 1992 and in revised form 3 December 1992.

1. Abbreviations used in this paper: $\mathrm{A} 9 \mathrm{C}$, anthracene-9-carboxylic acid; $\mathrm{CF}$, cystic fibrosis; CFTR, CF transmembrane conductance regulator; $\mathrm{Cl}$, chloride; DIDS, 4,4'-diisothiocyano-2,2'-stilbene disulfonic acid; dNT, deoxynucleotide; IAA94, indanyloxyacetic acid 94 .

J. Clin. Invest.

(c) The American Society for Clinical Investigation, Inc.

0021-9738/93/03/1253/05 \$2.00

Volume 91, March 1993, 1253-1257 absent in tissues expressing the CF defect $(1,2)$, and the identification, cloning, and sequencing of the $\mathrm{CF}$ gene (3-5). The $\mathrm{CF}$ gene product $\mathrm{CF}$ transmembrane conductance regulator (CFTR) is a large membrane-spanning protein responsible for cAMP-activated chloride transport. Normal chloride channel activation can be restored to CF cells in vitro by transfection with genetic material expressing normal CFTR $(6,7)$. Evidence to date supports the proposal that CFTR not only regulates, but is itself an epithelial chloride channel (8-12).

Information regarding the expression, regulation, and function of CFTR in the different cell types affected by the disease will become crucial to devising new tissue-specific therapeutic options. Mutations in CFTR alter chloride permeability in the sweat gland and inhibit chloride channel activation by cAMP but not by calcium in respiratory epithelium $(1,2)$. In the pancreas, defective pancreatic fluid (13) and chloride secretion (14) were clearly demonstrated in patients with CF and account for the pancreatic pathology in this disease. CFTR messenger RNA is expressed in pancreatic tissue (4), and CFTR protein has been localized to the apical membranes of proximal pancreatic duct cells immunohistochemically (15). Chloride channels activated by cAMP have been demonstrated in tissue of human fetal and animal pancreatic duct origin (16-18), and the CF pancreatic duct cell line CFPAC demonstrated defective cAMP-activated chloride channels (19). Despite this, study of pancreatic chloride transport and CFTR has been limited.

The PANC 1 cell line of human pancreatic duct cell origin retains a variety of differentiated epithelial cell characteristics (20). Even when grown on plastic, it retains a polarized cell configuration with apical microvilli, a centrally located nucleus, and apical vesicles. It expresses abundant chloride channels by patch-clamp technique (21), but these channels were identified and characterized as outwardly rectifying anion channels, now thought not to represent CFTR (22). The small conductance anion channel that is the current candidate for CFTR $(12,23)$ has not been studied. While identification of a faint band of CFTR genetic material was recently reported in PANC 1 after PCR amplification of reverse-transcribed poly(A)+ RNA (22), CFTR protein has not been identified in these cells.

The aim of this study was to determine if PANC 1 cells possess chloride conductances, in particular, the cAMP-activated chloride conductance, CFTR. To examine chloride conductance, we used electronic cell sizing to measure changes in cell volume under isotonic conditions in response to pharmacologic stimulation. Under isotonic conditions, stimulation of the movement of both anion and cation out of the cell, with the subsequent loss of fluid, is associated with a reduction in cell volume. Inhibition of cell volume changes by specific ion transport inhibitors can be used to identify specific ion channel acti- 
vation (24). To identify CFTR, we used oligo-dNT, synthesized to correspond to a 24-base sequence in the $5^{\prime}$ end of the human CFTR transcript. The complimentary or antisense sequence, when taken up by the cell, suppresses gene expression in a highly sequence-specific manner (25). Using antisense to CFTR, investigators have recently demonstrated uptake of oligo-dNT by human sweat duct cells in primary culture and inhibition of unstimulated chloride permeability (26). Antisense has also been used to suppress CFTR messenger RNA and protein expression in the colonic cell line T84, known to express abundant CFTR (27).

We report both cAMP and calcium-activated chloride conductances in PANC 1 cells. These conductances are pharmacologically distinct. The presence of a calcium-activated chloride conductance in the pancreatic duct cell permits the study of therapeutic options for CF in this organ directed at this unaffected channel. The identification of a cAMP-activated chloride conductance, abolished by CFTR antisense oligodeoxynucleotide, demonstrates that PANC 1 cells express CFTR, which can be detected functionally as a cAMP-activated cell volume reduction. These data also suggest that CFTR antisense provides a far more sensitive means of detecting the low levels of expression of CFTR in some cells than currently available.

\section{Methods}

Materials. Chemicals were obtained from the following sources: ${ }^{36} \mathrm{Cl}$ was purchased from ICN Biomedical (Irvine, CA); forskolin and ${ }^{8}$ BrcAMP from Sigma Chemical Co. (St Louis, MO); anthracene-9-carboxylic acid (A9C) from Aldrich Chemical Co. (Milwaukee, WI); DIDS from Molecular Probe (Eugene, OR); A23187 from Calbiochem (La Jolla, CA); and indanyloxyacetic acid 94 (IAA94) from Research Biochemical (Natick, MA).

PANC 1 cell culture. PANC 1 cells, obtained from the American Type Culture Collection (Rockville, MD), were grown on $175-\mathrm{cm}^{2}$ plastic flasks to confluence in DME supplemented with $25 \mathrm{mM} \mathrm{HCO}_{3}$ and $10 \%$ FCS. Medium was replaced twice weekly. Cells were split $1 / 5$, replated, and harvested on days 6-8 with $0.02 \%$ EDTA.

Electronic cell-sizing. Cells were resuspended in DME without $\mathrm{HCO}_{3}$, supplemented with $50 \mathrm{mM}$ Hepes, and incubated for $\geq 30 \mathrm{~min}$ at $37^{\circ} \mathrm{C}$. Aliquots of cell suspension were diluted to $30,000 \mathrm{cells} / \mathrm{ml}$ and examined by electronic cell-sizing as previously described (24) in an isotonic Hepes-buffered salt solution containing (in $\mathrm{mM}$ ): $140 \mathrm{NaCl}, 3$ $\mathrm{KCl}, 1 \mathrm{MgCl}_{2}, 1 \mathrm{CaCl}_{2}, 10$ glucose, and 10 Hepes. Cell volume was measured using a counter (model Zm; a Coulter Electronics Inc., Hialeah, FL) channelyzer (Coulter Electronics Inc.), and an X-Y recorder. Mean cell volume was calculated as the median of the distribution curves and relative cell volume was expressed as mean \pm SEM of duplicate or triplicate assays relative to the initial cell volume. Differences were compared by $t$ test.

Chloride transport studies. Cells were resuspended in an isotonic Hepes-buffered salt solution containing (in $\mathrm{mM}$ ): $115 \mathrm{NaCl}, 5.9 \mathrm{KCl}$, $2.1 \mathrm{KH}_{2} \mathrm{PO}_{4}, 2.5 \mathrm{CaCl}_{2}, 1.2 \mathrm{MgCl}_{2}, 11.5$ glucose, 0.3 L-glutamine, 25 Hepes, $0.02 \%$ soybean trypsin inhibitor, and $1 \%$ BSA. They were loaded with ${ }^{36} \mathrm{Cl} 5.5 \mu \mathrm{Ci} / \mathrm{ml}$ to steady state, resuspended in $\mathrm{Cl}$-free medium containing (in $\mathrm{mM}$ ): $150 \mathrm{Na}$ gluconate, $10 \mathrm{Hepes,} \mathrm{and} 10$ mannitol, washed on filters (Millipore Corp., Bedford, MA) at timed intervals after exposure to agonists, inhibitors, or vehicle. ${ }^{36} \mathrm{Cl}$ remaining was analyzed per microgram DNA relative to initial values for each sample. Data are expressed as mean \pm SEM of $n$ experiments performed in duplicate and differences were compared by $t$ test.

Oligodeoxynucleotides. A 24-mer oligodeoxynucleotide complementary (antisense) and homologous (sense) to the human CFTR transcript were synthesized (Gene Assembler Plus synthesizer; Pharmacia Inc., Piscataway, NJ) cleaved and purified using Sephadex G-50 (Nick columns; Pharmacia Inc.) according to the manufacturer's protocol
Both oligo-dNT coded for bases 14-37 from the transcription initiation site as originally reported (4). For antisense experiments, cells were grown on $75-\mathrm{cm}^{2}$ flasks to confluence, and on days 6-7 after plating, cultures were washed with PBS and placed in serum-free medium. Either the antisense oligo-dNT, 5'-TTTCTCTGACCTGCTGTGATGTCA-3', or the sense oligo-dNT, 5'-TGACATCACAGCAGGTCAGAGAAA-3', was added, at the concentrations described to a total volume of $5 \mathrm{ml}$ of media, and maintained in culture in the presence of oligo-dNT for $24 \mathrm{~h}$ before harvesting. For experiments examining time and concentration dependence, cells were grown in $50-\mathrm{cm}^{2}$ flasks and oligo-dNT was added to a total volume of $3 \mathrm{ml}$ of media.

A second set of 21-mer oligodeoxynucleotides sense and antisense to bases 133-153 were also synthesized and cell volume reduction in response to ${ }^{8} \mathrm{BrcAMP}$ and $\mathrm{A} 23187$ was studied after $24 \mathrm{~h}$ incubation with the sense $5^{\prime}$-ATGCAGAGGTCGCCTCTGGAA-3' or antisense 5'-TTCCAGAGGCGACCTCTGCAT-3' as described above.

\section{Results}

Cyclic AMP-activated chloride conductance. Under isotonic conditions, PANC 1 cells in suspension demonstrated a mean cell volume of $2.10 \pm 0.03 \mathrm{pl}(n=76$, mean \pm SEM). During 10 min of observation, cell volume relative to initial values remained stable. In the presence of the membrane-permeable analogue of cAMP, ${ }^{8} \mathrm{BrcAMP} 5 \times 10^{-4} \mathrm{M}$, mean cell volume decreased rapidly in a reproducible fashion (Fig. 1). By $2 \mathrm{~min}$, cell volume had decreased $5 \%$ (relative cell volume $0.95 \pm 0.01$, $n=9$ ) and at $10 \mathrm{~min}$ was significantly lower (relative cell volume: $0.89 \pm 0.01, n=9, P<0.005$ ) than control cell volume $(0.97 \pm 0.02, n=8)$. The volume reduction at $10 \mathrm{~min}$ in response to CAMP was abolished in the presence of the chloride channel inhibitor, $\mathrm{A} 9 \mathrm{C} 10^{-3} \mathrm{M}$. This inhibition by $\mathrm{A} 9 \mathrm{C}$ was specific. Neither the $\mathrm{Cl} / \mathrm{HCO}_{3}$ exchange inhibitor, DIDS $10^{-4}$ $\mathrm{M}$, nor the $\mathrm{Cl}$ channel inhibitor, IAA94 $2.4 \times 10^{-4} \mathrm{M}$, had any effect. These data demonstrate the activation by cAMP of an A9C-sensitive $\mathrm{Cl}$ channel during cell volume reduction.

To support these findings, we loaded PANC 1 cells in suspension with ${ }^{36}$ chloride and examined loss of labeled chloride at $5 \mathrm{~min}$ in response to agonists and inhibitors (Table I). The percent of ${ }^{36} \mathrm{Cl}$ lost at $5 \mathrm{~min}$ was significantly increased by both forskolin, a direct activator of adenyl cyclase $(P<0.02, n=6)$, and ${ }^{8} \operatorname{BrcAMP}(P<0.01, n=8)$ compared to vehicle. The $\mathrm{Cl}$ channel blocker, A9C $10^{-3} \mathrm{M}$, inhibited cAMP-activated ${ }^{36} \mathrm{Cl}$

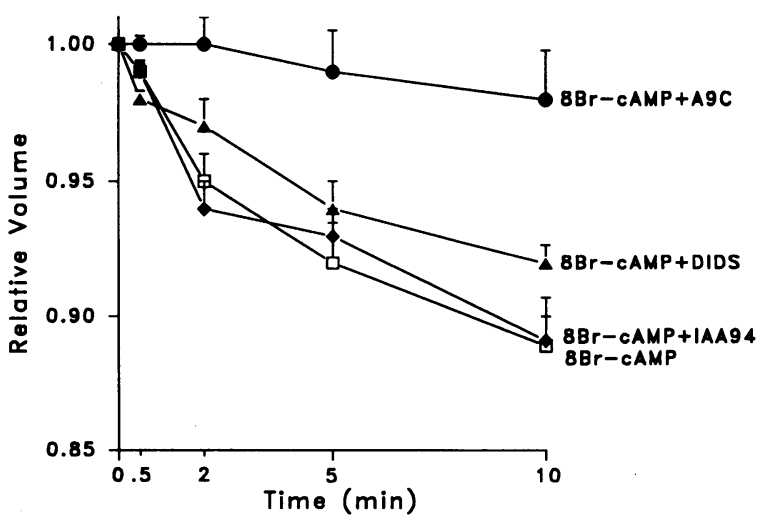

Figure 1. Relative cell volume in response to ${ }^{8} \mathrm{BrcAMP}$. In response to ${ }^{8} \mathrm{BrcAMP}\left(5 \times 10^{-4} \mathrm{M}\right)$, relative cell volume decreased significantly at $10 \min (P<0.005, n=9)$. The effect of ${ }^{8} \mathrm{BrcAMP}$ was abolished in the presence of the $\mathrm{Cl}$ channel inhibitor $\mathrm{A} 9 \mathrm{C}(n=5)$, but was unaffected by either the $\mathrm{Cl} / \mathrm{HCO}_{3}$ exchange inhibitor, $\operatorname{DIDS}(n=6)$, or the $\mathrm{Cl}$ channel blocker, IAA94 $(n=3)$. 
Table I. ${ }^{36} \mathrm{Cl}$ Secretion in PANC I Cells in Suspension

\begin{tabular}{ll}
\hline & \multicolumn{1}{c}{$\begin{array}{c}\text { Percentage } \mathrm{Cl} \\
\text { lost at } 5 \mathrm{~min}\end{array}$} \\
\hline Vehicle & $24.4 \pm 3.5(8)$ \\
Forskolin $\left(5 \times 10^{-5} \mathrm{M}\right)$ & $39.0 \pm 4.2(6) P<0.02$ \\
Forskolin $+\mathrm{A} 9 \mathrm{C}$ & $24.9 \pm 0.4(3)$ \\
${ }^{8} \mathrm{BrcAMP}\left(5 \times 10^{-4} \mathrm{M}\right)$ & $38.2 \pm 2.9(8) P<0.01$ \\
${ }^{8} \mathrm{BrcAMP}+\mathrm{DIDS}$ & $41.9 \pm 3.6(4) P<0.05$ \\
Ionomycin $\left(7 \times 10^{-7} \mathrm{M}\right)$ & $44.3 \pm 2.9(5) P<0.005$ \\
\hline
\end{tabular}

loss, but the stilbene exchange inhibitor, DIDS $10^{-4} \mathrm{M}$, had no effect.

Calcium-activated chloride conductance. PANC 1 cells in suspension also demonstrated evidence of a calcium-activated chloride conductance. In response to the calcium ionophore, ionomycin $10^{-7} \mathrm{M}$, there was a significant increase in ${ }^{36} \mathrm{Cl}$ loss at $5 \mathrm{~min}$ (Table I). The cell volume response to the calcium ionophore, A23187 $10^{-7} \mathrm{M}$, is shown in Fig. 2. PANC 1 cells in suspension decreased cell volume significantly at $10 \mathrm{~min}$ $(0.90 \pm 0.02, n=5, P<0.01)$. To confirm that the effect of A23187 was caused by an influx of extracellular calcium, the response to A23187 was examined in the presence of medium containing EGTA $(n=3)$ and in cells incubated with 1,2-bis(2aminophenoxy)ethane $\mathrm{N}, \mathrm{N}, \mathrm{N}^{\prime}, \mathrm{N}^{\prime}$-tetracetic acid $(n=5$, not shown). Both EGTA and 1,2-bis(2-aminophenoxy)ethane $\mathrm{N}, \mathrm{N}, \mathrm{N}^{\prime}, \mathrm{N}^{\prime}$-tetracetic acid treatment of cells abolished the cell volume response to A23187. In contrast to the effect of cAMP on cell volume, calcium-activated volume reduction in PANC 1 cells was abolished by the $\mathrm{Cl}$ channel inhibitor, IAA94. DIDS had no effect on calcium-activated volume reduction. At 5 and $10 \mathrm{~min}$, relative cell volume was $0.93 \pm 0.04$ and $0.88 \pm 0.02$, respectively (mean $\pm \mathrm{SE}, n=5$ ). A9C had some inhibitory effect on the volume response to A23187 but it was incomplete. At 5 and $10 \mathrm{~min}$, relative cell volume was $0.96 \pm 0.04$ and $0.93 \pm 0.04$, respectively $(n=6)$. These findings demonstrate the presence in PANC 1 cells of at least two different chloride conductances that can be distinguished pharmacologically: a

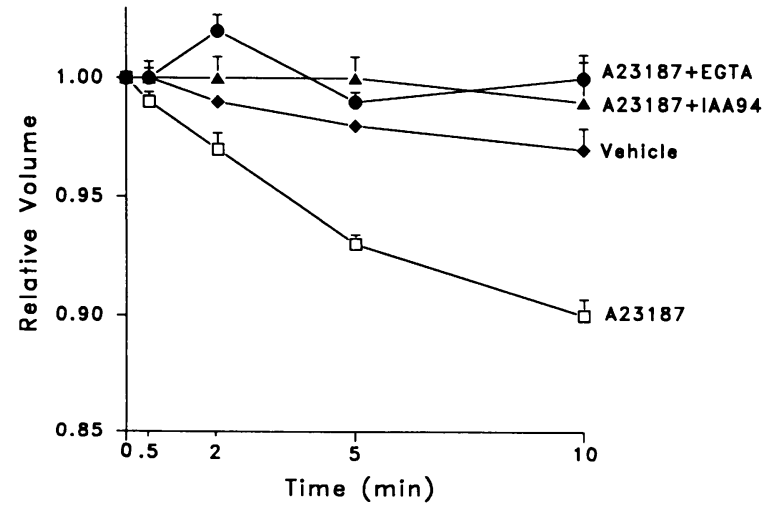

Figure 2. Relative cell volume in response to calcium. In response to the calcium ionophore, A23187 $\left(10^{-7} \mathrm{M}\right)$, relative cell volume decreased significantly at $10 \min (P<0.01, n=5)$. This effect was inhibited in the presence of EGTA $0.1 \mathrm{mM}(n=3)$, demonstrating that calcium was responsible for the volume reduction. Unlike the response to CAMP, calcium-activated volume reduction was inhibited by the chloride channel blocker, IAA94 $(n=4)$.

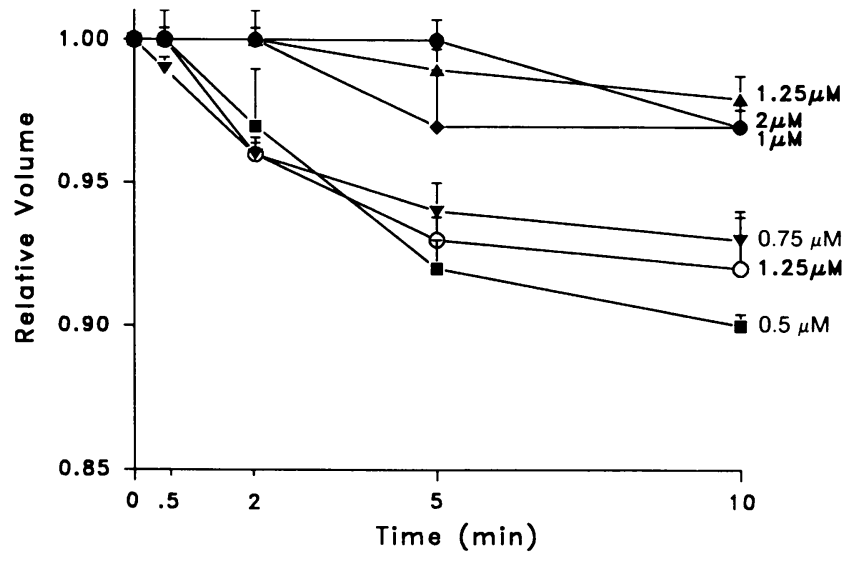

Figure 3. The effect of CFTR antisense oligodeoxynucleotide on cAMP-activated volume reduction. PANC 1 cells maintained in culture $24 \mathrm{~h}$ in the presence of $0.5 \mu \mathrm{M}$ antisense demonstrated an intact volume reduction in response to cAMP. As the concentration of antisense increased, the volume response to cAMP was increasingly attenuated. Sense oligodeoxynucleotide $1.25 \mu \mathrm{M}(\mathrm{O})$ had no effect. Data are a mean of three experiments in duplicate.

cAMP-activated $\mathrm{Cl}$ conductance sensitive to $\mathrm{A} 9 \mathrm{C}$ and a calcium-activated conductance sensitive to IAA94.

Cation Conductance. Cell volume reduction under isotonic conditions requires the movement of both anion and cation out of the cell with the subsequent loss of fluid. To identify the cation channel activated by CAMP and calcium during PANC 1 cell volume reduction, we examined the effect of barium, a potassium channel inhibitor, on cAMP and calcium-activated volume reduction. Barium $5 \mathrm{mM}$ prevented the cell volume reduction at $10 \mathrm{~min}$ in response to either ${ }^{8} \operatorname{BrcAMP}(0.97 \pm 0.02$, $n=5)$ or A23187 $(0.97 \pm 0.02, n=5)$, consistent with the activation of both chloride and potassium channels during volume reduction in PANC 1 cells.

CFTR expression in PANC 1. To determine if the cAMPactivated $\mathrm{Cl}$ conductance was caused by CFTR, we examined the effect of ${ }^{8} \mathrm{BrcAMP}$ on PANC 1 cells maintained in culture $24 \mathrm{~h}$ in the presence of CFTR antisense oligo dNT. Fig. 3 examines the effect of incubation with varying concentrations of antisense on cAMP-activated volume reduction. In response to $0.5 \mu \mathrm{M}$ antisense, PANC 1 cells maintained an intact volume reduction response to ${ }^{8} \mathrm{BrcAMP}$. As the concentration of antisense preincubation increased, the volume response to ${ }^{8}$ BrcAMP became increasingly attenuated. Cells preincubated with more than $1 \mu \mathrm{M}$ antisense no longer responded to ${ }^{8}$ BrcAMP. In contrast, cells incubated with sense oligo-dNT continued to demonstrate a significant volume reduction in response to CAMP.

Fig. 4 demonstrates the specificity of the CFTR antisense inhibition for cAMP-activated volume reduction. Cells were incubated for varying times with $2 \mu \mathrm{M}$ antisense. In Fig. $4 \mathrm{~A}$, volume reduction is examined in response to ${ }^{8} \mathrm{BrcAMP}$; in Fig. $4 \mathrm{~B}$, volume reduction is examined in response to the calcium ionophore, A23187. Antisense had no effect on volume reduction in response to calcium. Even after $24 \mathrm{~h}$ of $2 \mu \mathrm{M}$ antisense, A23187 caused a significant volume reduction over $10 \mathrm{~min}$. In contrast, the volume response to ${ }^{8} \mathrm{BrcAMP}$ became increasingly attenuated as the time of antisense incubation increased. $10 \mathrm{~h}$ of incubation with CFTR antisense was sufficient to abolish the response to cAMP. 


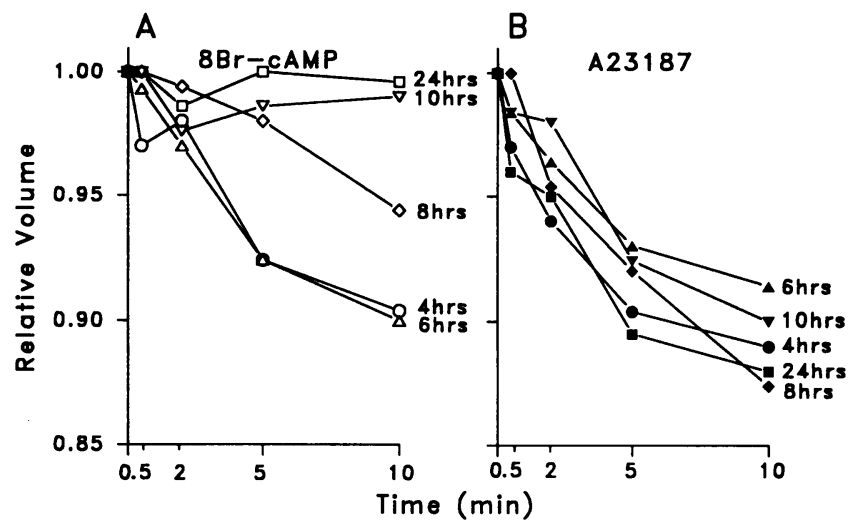

Figure 4. The time-dependent effect of CFTR antisense oligodeoxynucleotide on cAMP-activated and calcium-activated volume reduction. PANC 1 cells were incubated for varying times with $2 \mu \mathrm{M}$ antisense. $(A)$ The volume response to cAMP was increasingly attenuated as the time of antisense incubation increased. $(B)$ Antisense had no effect on volume reduction in response to calcium. Data are for two experiments in duplicate.

We examined the volume response of PANC 1 cells to ${ }^{8} \mathrm{BrcAMP}$ and A23187 after $24 \mathrm{~h}$ incubation with a second pair of oligodeoxynucleotides sense and antisense to a different region of the CFTR gene transcript. We found that $1.25 \mu \mathrm{M}$ antisense abolished the response to cAMP $(0.98 \pm 0.006$ at 10 min) but not the response to A23187 $(0.91 \pm 0.003, n=3)$. Sense oligodeoxynucleotide had no effect ( ${ }^{8}$ BrcAMP: 0.91 \pm 0.003 ; A23187: 0.92 $\pm 0.006, n=3$ ).

\section{Discussion}

We have demonstrated that PANC 1 cells in suspension lose volume in response to either CAMP or calcium because of activation of potassium and chloride channels. At least two chloride channels in PANC 1 cells can be distinguished pharmacologically by their different sensitivities to chloride channel inhibitors and to CFTR antisense oligodeoxynucleotides. The calcium-activated chloride conductance, sensitive to IAA94, is unaffected by CFTR antisense. The cAMP-activated chloride conductance, sensitive to $\mathrm{A} 9 \mathrm{C}$, is inhibited by CFTR antisense in a concentration- and time-dependent fashion.

Traditional techniques for detection of CFTR, such as the use of CFTR antibody to detect CFTR protein, the use of Northern blots to detect CFTR mRNA, and even the use of PCR have not demonstrated CFTR expression in PANC 1 cells. Recently, investigators successfully demonstrated a faint band consistent with CFTR from a PCR-amplified product reverse-transcribed from PANC 1 poly(A)+ RNA (22). Our findings are unequivocal evidence that PANC 1 cells express CFTR. The functional detection of CFTR as a cAMP-activated volume reduction and the use of specific antisense to genetically confirm the CFTR identity provide a simple and far more sensitive means than currently available of detecting the low levels of expression of CFTR in some cell types. The expression of CFTR in PANC 1 at these low but functionally important levels may make PANC 1 cells a better model for functional studies of the regulation of CFTR expression than T84 cells or genetically engineered systems that overexpress CFTR relative to physiologic levels.
Patch clamp studies in respiratory $(28,29)$ and colonic $(30)$ epithelia have demonstrated at least two distinct chloride channels responsible for regulated secretion. CFTR is responsible for cAMP but not calcium-activated chloride conductance (2), and the latter remains intact in patients with cystic fibrosis. Our findings demonstrate that the pancreatic duct cell, like respiratory and colonic epithelial cells, also possesses a calcium-activated chloride conductance whose function may, therefore, be amenable to therapeutic augmentation in an effort to compensate for defective CFTR function.

Our use of electronic cell sizing to measure cell volume reduction under isotonic conditions is supported by previous work on ion transport in both symmetrical and, more recently in polar epithelial cells (31). We demonstrated that cell volume reduction in PANC 1 cells was abolished by inhibitors of either potassium or chloride conductance, identifying these ions as involved in pancreatic cell volume reduction and presumably fluid secretion. While patch-clamp studies distinguished the two chloride conductances by their biophysical differences in current voltage relation, anion selectivity, and time dependence, our cell volume studies were able to differentiate them pharmacologically by their different sensitivities to channel inhibitors and to CFTR antisense oligodeoxynucleotides. Consistent with the observations made by patch-clamp studies on the small conductance anion channel of pancreatic duct cells (16, 18), cAMP-activated chloride loss was not sensitive to the stilbene anion exchanger, DIDS. Coupled with an experimental design using antisense transcripts, cell sizing provides an alternative technique to patch-clamp studies that is direct, sensitive, and specific for the identification and further examination of these pathways.

The study of pancreatic duct cell physiology and pathophysiology with respect to CFTR has to date relied on the ability to examine the small conductance chloride channel by patch clamping in at least two model systems: growth of primary pancreatic duct cell cultures from fetal tissue (16) and the $C F$ pancreatic adenocarcinoma cell line, CFPAC (19). We have presented evidence that PANC 1 cells express CFTR and can be transformed to a "CF" phenotype using antisense oligodeoxynucleotides. These cells may, therefore provide a useful model for studying the physiology of CF pancreatic duct cells as well.

\section{Acknowledgments}

The authors thank R. John MacLeod for introducing them to the technique of electronic cell sizing and the concept of cell volume measurement in the study of ion transport.

This work was supported by grants from the Canadian Cystic Fibrosis Foundation and the Medical Research Council of Canada. Dr. Kopelman is the recipient of a Canadian Cystic Fibrosis Foundation Scholar Award.

\section{References}

1. Quinton, Paul M. 1990. Cystic fibrosis: a disease in electrolyte transport. FASEB (Fed. Am. Soc. Exp. Biol.) J. 4:2709-2717.

2. Welsh, Michael J. 1990. Abnormal regulation of ion channels in cystic fibrosis epithelia. FASEB (Fed. Am. J.) 4:2718-2725.

3. Rommens, J. M., M. C. Iannuzzi, B. Kerem, M. L. Drumm, G. Melmer, M. Dean, R. Rozmahel, J. L. Cole, D. Kennedy, N. Hidaka, et al. 1989. Identification of the cystic fibrosis gene: chromosome walking and jumping. Science (Wash. DC). 245:1059-1065. 
4. Riordan, J. R., J. M. Rommens, B. S. Kerem, N. Alon, R. Rozmahel, Z. Grzelczak, J. Zielenski, S. Lok, N. Plavsic, et al. 1989. Identification of the cystic fibrosis gene: cloning and characterization of complementary DNA. Science (Wash. DC). 245:1066-1073.

5. Kerem, B., J. M. Rommens, J. A. Buchanan, D. Markiewicz, T. K. Cox, A. Chakravarti, M. Buchwald, and L.-C. Tsui. 1989. Identification of the cystic fibrosis gene: genetic analysis. Science (Wash. DC). 245:1073-1080.

6. Drumm, M. L., H. A. Pope, W. H. Cliff, J. M. Rommens, S. A. Marvin, L.-C. Tsui, F. S. Collins, R. A. Frizzell, J. M. Wilson. 1990. Correction of the cystic fibrosis defect by retro virus-mediated gene transfer. Cell. 62:1227-1233.

7. Rich, D. P., M. P. Anderson, R. J. Gregory, S. H. Cheng, S. Paul, D. M. Jefferson, J. D. McCann, K. W. Klinger, A. E. Smith, and M. J. Welsh. 1990. Expression of cystic fibrosis transmembrane conductance regulator corrects defective chloride channel regulation in cystic fibrosis airway epithelial cells. Nature (Lond.). 347:358-363.

8. Anderson, M. P., D. P. Rich, R. J. Gregory, A. E. Smith, and M. J. Welsh. 1991. Generation of cAMP-activated chloride currents by expression of CFTR. Science (Wash. DC). 251:679-682.

9. Kartner, N., J. W. Hanrahan, T. J. Jensen, A. L. Naismith, S. Z. Sun, C. A. Ackerly, E. F. Reyes, L. C. Tsui, J. M. Rommens, C. E. Bear, et al. 1991. Expression of the cystic fibrosis gene in non-epithelial invertebrate cells produces a regulated anion conductance. Cell. 64:681-691.

10. Berger, H. A., M. P. Anderson, R. J. Gregory, S. Thompson, P. W. Howard, R. A. Maurer, R. Mulligan, A. E. Smith, and M. J. Welsh. 1991. Identification and regulation of the cystic fibrosis transmembrane conductance regulatorgenerated chloride channel. J. Clin. Invest. 88:1422-1431.

11. Bear, C. E., F. Duguay, A. L. Naismith, N. Kartner, J. W. Hanrahan, and J. R. Riordan. 1991. $\mathrm{Cl}^{-}$channel activity in xenopus oocytes expressing the cystic fibrosis gene. J. Biol. Chem. 266:19142-19145.

12. Anderson, M. P., R. J. Gregory, S. Thompson, D. W. Souza, S. Paul, R. C Mulligan, A. E. Smith, and M. J. Welsh. 1991. Demonstration that CFTR is a chloride channel by alteration of its anion selectivity. Science (Wash. DC). 253:202-205.

13. Kopelman, H., P. Durie, K. Gaskin, Z. Weizman, and G. Forstner. 1985 Pancreatic fluid secretion and protein hyperconcentration in cystic fibrosis. $N$ Engl. J. Med. 312:329-333.

14. Kopelman, H., M. Corey, K. Gaskin, P. Durie, Z. Weizman, and G. Forstner. 1988. Impaired chloride secretion as well as bicarbonate secretion underlies the fluid secretory defect in the cystic fibrosis pancreas. Gastroenterology. 95:349-355.

15. Marino, C. R., L. M. Matovcik, F. S. Gorelick, and J. A. Cohn. 1991 Localization of the cystic fibrosis transmembrane conductance regulator in pancreas. J. Clin. Invest. 88:712-716.

16. Gray, M. A., A. Harris, L. Coleman, J. R. Greenwell, and B. E. Argent 1989. Two types of chloride channels on duct cells cultured from fetal pancreas. Am. J. Physiol. 257:C240-C251.

17. Novak, I., R. Greger. 1988. Properties of the luminal membrane of iso- lated perfused rat pancreatic ducts. Effect of cyclic AMP and blockers of chloride transport. Pfluegers Arch. 411:546-553.

18. Gray, M. A., J. R. Greenwell, and B. E. Argent. 1988. Secretin-regulated chloride channel on the apical plasma membrane of pancreatic duct cells. $J$. Membr. Biol. 105:131-142.

19. Schoumacher, R. A., J. Ram, M. C. Iannuzzi, N. A. Bradbury, R. W. Wallace, C. T. Hon, D. R. Kelly, S. M. Schmid, F. B. Gelder, T. A. Rado, and R. A. Frizzell. 1990. A cystic fibrosis pancreatic adenocarcinoma cell line. Proc. Natl. Acad. Sci. USA. 87:4012-4016.

20. Madden, M. E., and M. P. Sarras. 1988. Morphological and biochemical characterization of a human pancreatic duct cell line (PANC 1). Pancreas 3:512 528.

21. Hanrahan, J. W., and J. A. Tabcharani. 1989. The role of the outwardly rectifying anion channel in epithelial chloride and bicarbonate transport. Ann. NY Acad. Sci. 2-8546.

22. Ward, C. L., M. E. Krouse, D. C. Gruenert, R. R. Kopito, and J. J. Wine. 1991. Cystic fibrosis gene expression is not correlated with rectifying chloride channels. Proc. Natl. Acad. Sci. USA. 88:5277-5281.

23. Tabcharani, J. A., X. B. Chang, J. R. Riordan, and J. W. Hanrahan. 1991. Phosphorylation-regulated $\mathrm{Cl}$ channel in $\mathrm{CHO}$ cells stably expressing the cystic fibrosis gene. Nature (Lond.). 352:628-631.

24. MacLeod, R. J., and J. R. Hamilton. 1990. Regulatory volume increase in mammalian jejunal villus cells is due to bumetanide-sensitive $\mathrm{NaKCl} 2$ cotransport. Am. J. Physiol. 258:G665-G674.

25. Izant, J. G., and H. Weintraub. 1985. Constitutive and conditional suppression of exogenous and endogenous genes by antisense RNA. Science (Wash. DC). 229:345-352.

26. Sorscher, E. J., K. L. Kirk, M. L. Weaver, T. Jilling, J. E. Blalock, R. D. LeBoeuf. 1991. Antisense oligodeoxynucleotide to the cystic fibrosis gene inhibits anion transport in normal cultured sweat duct cells. Proc. Natl. Acad. Sci. USA. 88:7759-7762.

27. Wagner, J. A., T. V. McDonald, P. T. Nghiem, A. W. Lowe, H. Schulman, D. C. Gruenert, L. Stryer, and P. Gardner. 1992. Antisense oligodeoxynucleotides to the cystic fibrosis transmembrane conductance regulator inhibit cAMPactivated but not calcium-activated chloride currents. Proc. Natl. Acad. Sci. USA. 89:6785-6789

28. Frizzell, R. A., G. Rechkemmer, and R. L. Shoemaker. 1986. Altered regulation of airway epithelial cell chloride channels in cystic fibrosis. Science (Wash. DC). 233:558-560.

29. Anderson, M. P., and M. J. Welsh. 1991. Calcium and cAMP activate different chloride channels in the apical membrane of normal and cystic fibrosis epithelia. Proc. Natl. Acad. Sci. USA. 88:6003-6007.

30. Cliff, W. H., and R. A. Frizzell. 1990. Separate chloride conductances activated by cAMP and $\mathrm{Ca}$ in $\mathrm{Cl}$ secreting epithelial cells. Proc. Natl. Acad. Sci. USA. 87:4956-4960.

31. Sarkadi, B., and J. C. Parker. 1991. Activation of ion transport pathways by changes in cell volume. Biochim. Biophys. Acta. 1071:407-427. 